\title{
ISOTHERMAL OXIDATION BEHAVIOR OF ELECTROSPARK DEPOSITED NiCrAIY COATINGS ON A NI-BASED SINGLE-CRYSTAL SUPERALLOY
}

\author{
IZOTERMIČNA OKSIDACIJA MED ELEKTROISKRILNIM \\ NANAŠANJEM NiCrAIY PREVLEKE NA MONOKRISTAL Ni \\ SUPERZLITINE
}

\author{
Cean Guo ${ }^{1,3}$, Ting Liang ${ }^{1}$, Fengsheng $\mathrm{Lu}^{2}$, Zhengang Liang ${ }^{1}$, Shuang Zhao ${ }^{1}$, Jian Zhang ${ }^{1 *}$ \\ ${ }^{1}$ Shenyang Ligong University, School of Equipment Engineering, no. 6 Nanping Central Road, Hunnan New District, Shenyang 110159 , \\ Liaoning, China \\ ${ }^{2}$ North Huaan Industry Group Limited Company, no. 28 Renping Road, Nianzishan District, Qiqihaer 161046, Heilongjiang, China \\ ${ }^{3}$ Chongqing Jianshe Industry (Group) Limited Liability Company, no. 1 Jianshe Road, Banan District, Chongqing 400054, China
}

Prejem rokopisa - received: 2018-09-28; sprejem za objavo - accepted for publication: 2018-12-17

doi:10.17222/mit.2018.210

\begin{abstract}
The isothermal oxidation behavior of a NiCrAlY coating prepared by means of electrospark deposition (ESD) technology on second-generation Ni-based single-crystal DD6 was investigated at $1100{ }^{\circ} \mathrm{C}$ for $100 \mathrm{~h}$. Surface morphologies, chemical composition, and the phase constitution of the coating were analyzed by scanning electron microscopy (SEM), energy-dispersive spectrometer (EDS) and X-ray diffraction (XRD). The results showed that the as-deposited NiCrAlY coating, with uniform superfine columnar crystals and nanocrystallines, consists of $\beta$-NiAl and $\gamma$-Ni double phases; the oxidation resistance of the DD6 alloy was greatly improved by depositing the NiCrAlY coating, which was covered by two layers of oxides, $\theta-\mathrm{Al}_{2} \mathrm{O}_{3}$ and $\alpha-\mathrm{Al}_{2} \mathrm{O}_{3}$, while three layers of oxides, including $\mathrm{Ni}(\mathrm{Co}) \mathrm{O}, \mathrm{NiCr}_{2} \mathrm{O}_{4}, \mathrm{CrTaO}_{4}, \mathrm{CoTa}_{2} \mathrm{O}_{6}$ and $\alpha-\mathrm{Al}_{2} \mathrm{O}_{3}$, formed on the DD6 superalloy; the interdiffusion zone (IDZ) and secondary reaction zone (SRZ) formed between the NiCrAlY coating and the DD6 superalloy substrate for the interdiffusion; however, no deleterious Kirkendall voids appeared, which may be mainly due to the gradient transition of the elements between the coating and the substrate.
\end{abstract}

Keywords: isothermal oxidation, NiCrAlY coating, electrospark deposition, Ni-based single-crystal superalloy

Avtorji so raziskovali izotermično oksidacijo NiCrAlY prevleke, pripravljene s tehnologijo elektroiskrilne depozicije (ESD), na drugo generacijo monokristala iz Ni superzlitine DD6 pri času zadrževanja 100 ur na temperaturi $1100{ }^{\circ} \mathrm{C}$. Površinsko morfologijo nastale prevleke ter njeno kemično in fazno sestavo so analizirali z vrstičnim elektronskim mikroskopom (SEM), energijskim disperzijskim spektrometrom (EDS) in rentgensko difrakcijo (XRD). Rezultati raziskave kažejo, da ima nanešena NiCrAlY prevleka enovite superdrobne stebričaste kristale in nanokristalite ter vsebuje $\beta$-NiAl in $\gamma$-Ni dvojne faze. Z nanosom NiCrAlY prevleke se je močno izboljšala odpornost DD6 zlitine proti oksidaciji. Na DD6 superzlitini nastala prevleka je bila sestavljena iz dveh plasti oksidov, $\theta-\mathrm{Al}_{2} \mathrm{O}_{3}$ in $\alpha-\mathrm{Al}_{2} \mathrm{O}_{3}$ medtem ko je tretja plast vsebovala okside $\mathrm{Ni}(\mathrm{Co}) \mathrm{O}, \mathrm{NiCr}_{2} \mathrm{O}_{4}, \mathrm{CrTaO}{ }_{4}$ $\mathrm{CoTa}_{2} \mathrm{O}_{6}$ in $\alpha-\mathrm{Al}_{2} \mathrm{O}_{3}$. Interdifuzijska cona (IDZ) in sekundarna reakcijska cona (SRZ) sta nastali med NiCrAlY prevleko in substratom iz DD6 superzlitine, vendar pa niso opazili škodljivega nastanka por zaradi Kirkendallovega efekta. Ta lahko nastopi zaradi gradientnega prenosa oz. različne hitrosti difuzije elementov s prevleke na substrat in obratno.

Ključne besede: izotermična oksidacija, NiCrAlY prevleka, elektroiskrilna depozicija, monokristal iz Ni superzlitine

\section{INTRODUCTION}

Ni-based single-crystal superalloys can have outstanding mechanical properties as high-pressure turbine blades that work at up to $80 \%$ of their absolute melting temperature. The demand for enhanced mechanical properties at higher temperature in Ni-based single-crystal superalloys has given rise to increasingly more additions of refractory elements such as Ta, W and Re, which comes at the cost of degrading the oxidation resistance. ${ }^{1-2}$ Therefore, coatings that possess excellent hightemperature oxidation resistance are necessities to protect the turbine blades from oxidizing and corroding during service.

*Corresponding author e-mail: 373055507@qq.com
Among the protective coating materials, MCrAlY ( $\mathrm{M}=\mathrm{Ni}$ and/or $\mathrm{Co}$ ) coatings, with a good balance of mechanical properties and oxidation resistance, have been most widely applied for the protection of the turbine blades. ${ }^{3-4}$ Generally, their deposition techniques include physical vapor deposition (PVD), conventional thermal spraying, low-pressure plasma spraying (LPPS) and high-velocity oxygen fuel (HVOF). However, the bond strength between the coating and the substrate obtained with these techniques needs to be further improved, and moreover, these techniques require expensive equipment and specific rooms. In contrast, electrospark depositon (ESD) is a promising technique to deposit coatings with a metallurgical bond between coating and substrate. Moreover, ESD is also relatively simple, cheap, and highly efficient for surface treatment. In addition, the coating deposition process is ecologi- 
cally safe and can be characterized by a low energy consumption, a high profitability and a rapid return on investment. ${ }^{5-6}$

ESD is a micro-welding process with a low heat input and high energy density. In the ESD process, the electrode (anode) and the substrate (cathode) are instantaneously touched and discharged, and then the physical and chemical reactions take place in their small melting pool to form a splat. Because of the short pulse duration and the high frequency during the deposition process, heat is generated in $1 \%$ of one pulse cycle, and then transferred in remaining $99 \%$ of one pulse cycle. Therefore, the cooling rate in the ESD process may reach in the range of $10^{5}-10^{6} \mathrm{C} / \mathrm{s}$, and such rapid solidification can be utilized to produce coatings containing nano-sized grains or even an amorphous structure. In recent years, using the ESD technique to deposit highperformance coating seems quite promising, such as chromium carbide-based coatings, ${ }^{7} \mathrm{Cu} / \mathrm{Cu}-\mathrm{MoS}_{2}$ selflubricating coatings, ${ }^{8}$ WC-Co coatings,${ }^{9}$ in-situ TiN coatings, ${ }^{10} \mathrm{Zr}$-based amorphous-nanocrystalline coatings, ${ }^{11} \mathrm{CuNiSiTiZr}$ high-entropy alloy coatings ${ }^{12}$ and W-Ni-Fe-Co coatings. ${ }^{13}$

However, most research about ESD coatings focused on the mechanical properties, so the oxidation resistance of ESD coatings still needs further investigations. Y. J. Xie et al. ${ }^{14}$ studied the isothermal oxidation behavior of an ESD NiCoCrAlYTa coating on a Ni-base superalloy IN-792, showing that the coating exhibits good oxidation resistance. To the best of our knowledge, there is still no relevant research report on isothermal oxidation behavior of ESD MCrAlY coating on a Ni-based single-crystal superalloy substrate, and therefore, the isothermal oxidation behavior of ESD NiCrAlY coatings on a Ni-based single crystal superalloy substrate will be investigated.

\section{MATERIALS AND METHODS}

A second-generation Ni-based single-crystal DD6 ingot was selected as the substrate material and its chemical composition is shown in Table 1. The bar of DD6 superalloy was processed disk-shape specimens with size of $\phi 20 \mathrm{~mm} \times 3 \mathrm{~mm}$, and the NiCrAlY alloy (nominal chemical composition: $27 w / \% \mathrm{Cr}, 11 w / \% \mathrm{Al}$, $0.5 w / \% \mathrm{Y}$, balance $\mathrm{Ni}$ ) was processed with a cylindershape electrode with size of $\phi 3 \mathrm{~mm} \times 40 \mathrm{~mm}$ by using wire electrical discharge machining. The specimens and electrode were ground using $\mathrm{SiC}$ abrasive paper to 1000 grit finish and ultrasonically cleaned within ethanol and acetone mixture. The NiCrAlY coating was prepared by utilizing a DJ-2000-type adjustable power metal surface repairing machine, and the preliminary optimized processing parameters set as outlined in Table 2. For the convenience of the discussion, thereafter the NiCrAlY coated DD6 specimen is referred to as the NiCrAlY coating.
Table 1: Chemical composition of DD6 superalloy $(w / \%)^{15}$

\begin{tabular}{|c|c|c|c|c|c|c|c|c|}
\hline $\mathrm{Cr}$ & $\mathrm{Co}$ & $\mathrm{Mo}$ & $\mathrm{W}$ & $\mathrm{Ta}$ & $\mathrm{Al}$ & $\mathrm{Hf}$ & $\mathrm{Re}$ & $\mathrm{Ni}$ \\
\hline 4.3 & 9 & 2 & 8 & 7.5 & 5.6 & 0.1 & 2 & $\mathrm{Bal}$ \\
\hline
\end{tabular}

Table 2: Processing parameters of ESD

\begin{tabular}{|c|c|c|c|}
\hline $\begin{array}{c}\text { Power } \\
\text { /W }\end{array}$ & $\begin{array}{c}\text { Argas flow } \\
/ \mathrm{L} \cdot \mathrm{min}^{-1}\end{array}$ & $\begin{array}{c}\text { Electrode } \\
\text { rotating rate } \\
/ \mathrm{r} \cdot \mathrm{min}^{-1}\end{array}$ & $\begin{array}{c}\text { Deposition time } \\
\text { unit area } \\
/ \mathrm{min} \cdot \mathrm{cm}^{-1}\end{array}$ \\
\hline 1000 & 15 & 3000 & 1.5 \\
\hline
\end{tabular}

An isothermal oxidation test of the DD6 and the NiCrAlY coating specimens was conducted in static air in a muffle furnace. Prior to the test, the alumina crucibles were kept at $1300{ }^{\circ} \mathrm{C}$ until no mass change was observed. The mass change of each specimen with a crucible was measured discontinuously by interrupting the oxidation process. An electronic balance (Sartorius BP211D) with a sensitivity of $10^{-5} \mathrm{~g}$ was used to measure the mass change of the specimens.

Surface morphologies were obtained by scanning electron microscopy (SEM, Inspect F50, FEI Co., Hillsboro, Oregon), while the energy-dispersive spectrometer (EDS, X-Max, Oxford instruments Co., Oxford, UK) was used to analyze the chemical composition of the selected area. The phase constitution of the coatings and the oxide scales was identified by X-ray diffraction (XRD, X' Pert PRO, PANalytical Co., Almelo, Holland).

\section{RESULTS AND DISCUSSION}

\subsection{As-deposited NiCrAlY coating microstructure}

Figure 1 shows the morphologies and EDS results of as-deposited NiCrAlY coating. It can be seen from Figure 1a that a typical splash feature appeared on the NiCrAlY coating surface. When the electrode and the

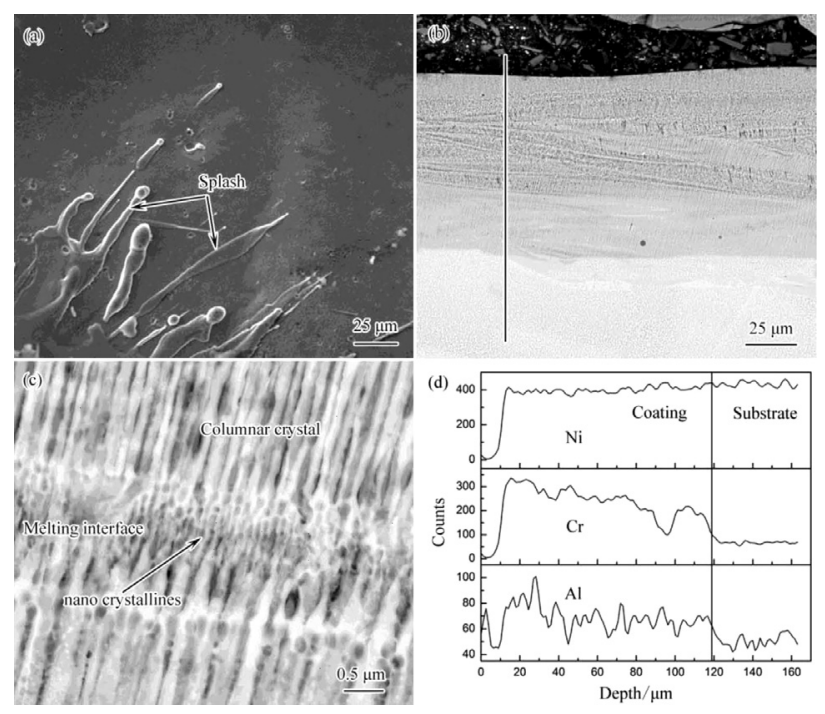

Figure 1: As-deposited NiCrAlY coating: a) surface morphology, b) overall cross-section morphology, c) high-magnification cross-section morphology, d) EDS line scanning 


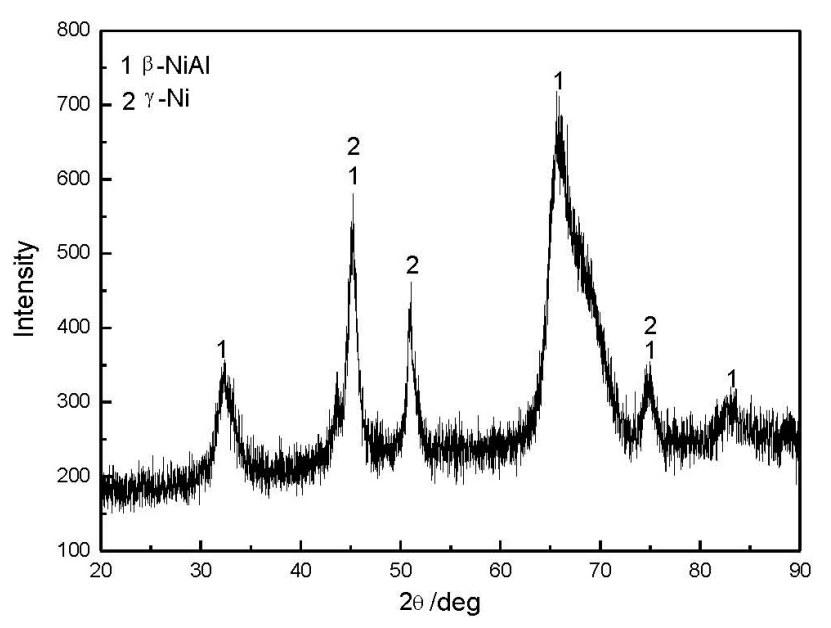

Figure 2: XRD pattern of as-deposited NiCrAlY coating

substrate come into contact in the form of a short circuit, the capacitor energy is instantaneously released. A plasma arc with a maximum temperature reaching $5000-25000 \mathrm{~K}$ is generated by the current pulse for a short time, and it induces a droplet formation at the end of the electrode, and then the plasma jet accelerates the droplet towards the substrate surface at high velocity to form a splash appearance. As shown in Figure 1b, a fully dense and crack-free coating was obtained using the ESD technique. It can be clearly seen from Figure 1c that the microstructure of the coating consists of uniform superfine columnar crystals with a column width of about $0.2 \mu \mathrm{m}$, and between the subsequent layers there is an obvious melting interface containing nanocrystallites. The cooling rates of the coating in the ESD process can reach $10^{5}-10^{6} \mathrm{~K} / \mathrm{s}$, and with such a rapid cooling speed the crystal nuclei grow up difficultly, resulting that the coating consists of micro-scale and even nano-scale structure. Figure 1d presents EDS line scanning of NiCrAlY coating, indicating that the elements in the electrode gradually transit from the coating to the substrate at the interface, which means an adherent metallur-

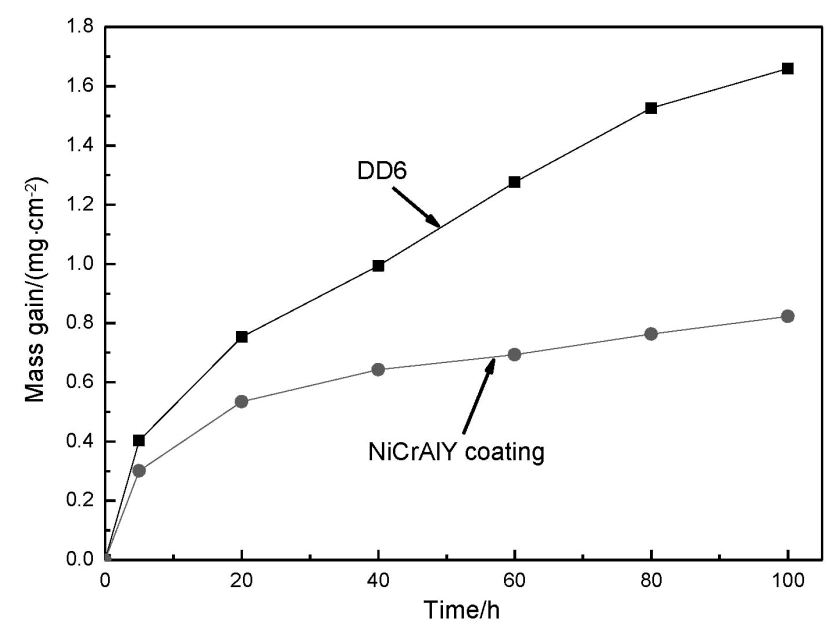

Figure 3: Oxidation kinetics curves of DD6 superalloy and NiCrAlY coating at $1100{ }^{\circ} \mathrm{C}$ for $100 \mathrm{~h}$ gical bond has been obtained. The XRD analysis results show that the as-deposited NiCrAlY coating consists of two phases of $\beta$-NiAl and $\gamma$-Ni (Figure 2).

\subsection{Oxidation kinetics curves}

Figure 3 shows the oxidation kinetics curves of DD6 superalloy and $\mathrm{NiCrAlY}$ coating at $1100{ }^{\circ} \mathrm{C}$ for $100 \mathrm{~h}$. Both the DD6 superalloy and the NiCrAlY coating followed an apparently parabolic rate law, but the oxidation behavior of the NiCrAlY coating was far superior to that of the DD6 superalloy, and after $100 \mathrm{~h}$ its weight gain was only half that of the latter, indicating that the oxidation resistance of DD6 alloy was obviously improved by depositing the NiCrAlY coating.

\subsection{Oxidation analysis}

Figure 4 shows XRD patterns of the DD6 superalloy and the NiCrAlY coating oxidized at $1100{ }^{\circ} \mathrm{C}$ for $100 \mathrm{~h}$. For the DD6 superalloy, the complex oxide peaks, including $\alpha-\mathrm{Al}_{2} \mathrm{O}_{3}, \mathrm{Ni}(\mathrm{Co}) \mathrm{O}, \mathrm{NiCr}_{2} \mathrm{O}_{4}, \mathrm{CrTaO}_{4}$ and $\mathrm{CoTa}_{2} \mathrm{O}_{6}$, were identified. For the NiCrAlY coating, two kinds of oxides, $\theta-\mathrm{Al}_{2} \mathrm{O}_{3}$ and $\alpha-\mathrm{Al}_{2} \mathrm{O}_{3}$, appeared. Meanwhile, only $\gamma$-Ni was identified below the oxides for both the DD6 superalloy and the NiCrAlY coating.

Figure 5 presents the surface morphology and EDS results of the DD6 superalloy oxidized at $1100{ }^{\circ} \mathrm{C}$ for $100 \mathrm{~h}$. Many granular oxides closely appeared on the surface of the DD6 superalloy, and moreover, there were holes and cracks distributed among the granular oxides (Figure 5a). The area A EDS results showed that the chemical composition of the oxides contained $56.54 \times 1 \%$ $\mathrm{O}, 38.45 \times / \% \mathrm{Ni}, 3.89 x / \% \mathrm{Co}$ and $1.13 \times / \% \mathrm{Cr}$ (Figure $5 \mathbf{b}$ ), and combining with the $\mathrm{XRD}$ results, this is believed to be $\mathrm{Ni}(\mathrm{Co}) \mathrm{O}$ and minor $\mathrm{NiCr}_{2} \mathrm{O}_{4}$.

Figure 6 presents the surface morphology and EDS results of NiCrAlY coating oxidized at $1100{ }^{\circ} \mathrm{C}$ for $100 \mathrm{~h}$. A large amount of blade-like oxides covered on the surface of the NiCrAlY coating (Figure 6a), and the

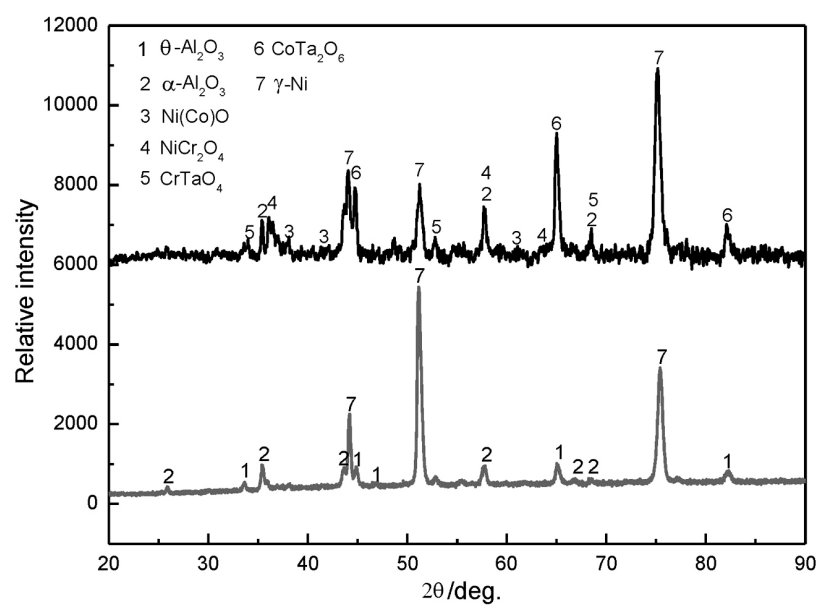

Figure 4: XRD patterns of DD6 superalloy and NiCrAlY coating oxidized at $1100{ }^{\circ} \mathrm{C}$ for $100 \mathrm{~h}$ 

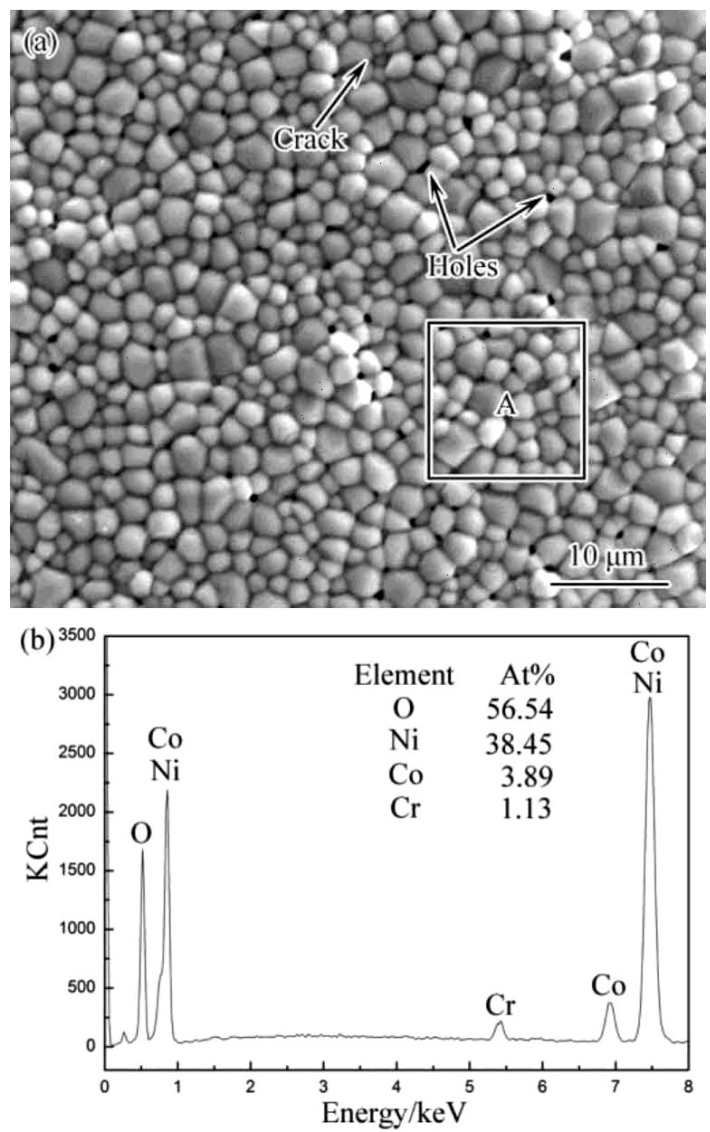

Figure 5: DD6 superalloy oxidized at $1100{ }^{\circ} \mathrm{C}$ for $100 \mathrm{~h}$ : a) surface morphology, b) area A EDS results

area B EDS results showed that the chemical composition of the oxides contained $57.90 \times 1 \%$ O, $38.54 \times 1 \%$ $\mathrm{Al}, 2.48 \times 1 \% \mathrm{Cr}$ and $1.08 \times 1 \% \mathrm{Ni}$ (Figure 6b). From the $\mathrm{XRD}$ results and the typical morphology, the blade-like oxide is believed to be $\theta-\mathrm{Al}_{2} \mathrm{O}_{3}$.

Figure 7 presents cross-section morphology and EDS mapping of DD6 superalloy oxidized at $1100{ }^{\circ} \mathrm{C}$ for $100 \mathrm{~h}$. The three layers of oxides formed on the DD6 superalloy, i.e. the gray granular oxide, the gray and light one, and the dark one from top to bottom. The EDS mapping revealed that a strong signal of $\mathrm{Ni}$ was detected in the top layer, which suggests the oxide of this layer belongs to $\mathrm{Ni}(\mathrm{Co}) \mathrm{O}$; strong signal of $\mathrm{Co}, \mathrm{Cr}$, Ta was shown in the middle layer, and from the XRD results, this is believed to be $\mathrm{CrTaO}_{4}$ and $\mathrm{CoTa}_{2} \mathrm{O}_{6}$; strong signal of $\mathrm{Al}$ was displayed in the bottom layer, combining with the XRD results, the dark layer is $\alpha-\mathrm{Al}_{2} \mathrm{O}_{3}$. In addition, the transformation of $\gamma / \gamma^{\prime}$ to $\gamma$ took place underneath the scales due to the consumption of Al during the high-temperature oxidation.

Many oxides can form in the early stage at $1100{ }^{\circ} \mathrm{C}$ for DD6 superalloy, and Table 3 shows standard free energy of forming oxides when reacted with $1 \mathrm{~mol} \mathrm{O}_{2} \cdot{ }^{16}$ As forming oxides of $\mathrm{Cr}$ and $\mathrm{W}$ are volatile at $1100{ }^{\circ} \mathrm{C}$, they are not shown in the Table 3. As shown in Table 3, in the early stage of oxidation, the $\mathrm{Al}_{2} \mathrm{O}_{3}$ rapidly formed
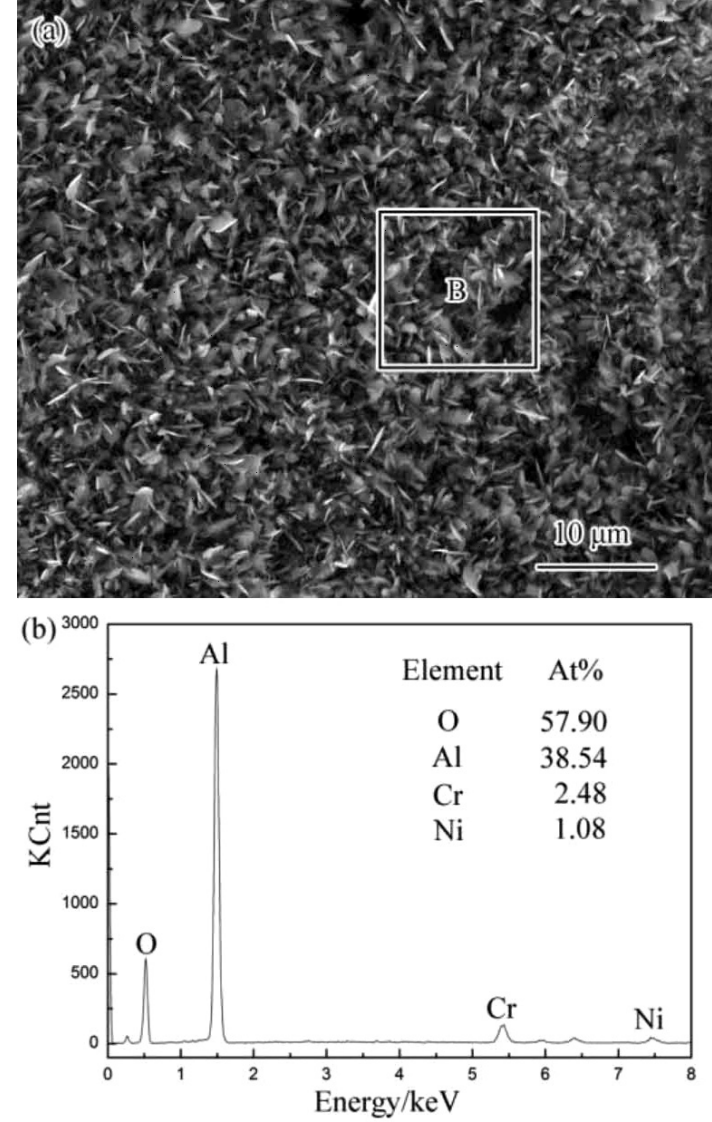

Figure 6: NiCrAlY coating oxidized at $1100{ }^{\circ} \mathrm{C}$ for $100 \mathrm{~h}$ : a) surface morphology, b) area B EDS results

first due to the fact that $\mathrm{Al}$ has the highest affinity for $\mathrm{O}$; however, the formed $\mathrm{Al}_{2} \mathrm{O}_{3}$ film could not completely cover the DD6 superalloy due to the lower content, i.e. the oxide scales are influenced not only by the thermodynamics, but also by the dynamics. Thus, since the content of $\mathrm{Ni}(\mathrm{Co})$ was the highest, during the second stage, the $\mathrm{Ni}$ and Co cations diffused outwards to form $\mathrm{Ni}(\mathrm{Co}) \mathrm{O}$ at the oxide/gas interface, and with the growing up rapidly of the $\mathrm{Ni}(\mathrm{Co}) \mathrm{O}$ layer, the previously formed $\mathrm{Al}_{2} \mathrm{O}_{3}$ film spalled. At the same time, the $\mathrm{O}$ diffused inward through the newly formed $\mathrm{Ni}(\mathrm{Co}) \mathrm{O}$ layer to react with $\mathrm{Cr}$, Ta, $\mathrm{W}$ cations to generate the other compounds, and then $\mathrm{CrTaO}_{4}$ and $\mathrm{CoTa}_{2} \mathrm{O}_{6}$ spinel phases in the middle layer. In the last stage, with the growing up of the middle layer, the diffusion rate of $\mathrm{O}$ through the middle layer became slower to cause the $\mathrm{O}$ partial pressure at the oxide/metal interface to attain a critical value, then a continuous compact $\alpha-\mathrm{Al}_{2} \mathrm{O}_{3}$ layer built up under the middle layer. Finally, the oxidation rate greatly reduced as it became governed by the transport through the growing of the $\alpha-\mathrm{Al}_{2} \mathrm{O}_{3}$ layer.

Table 3: Standard free energy of forming oxides when reacted with $1 \mathrm{~mol} \mathrm{O}_{2}$

\begin{tabular}{|c|c|c|c|c|}
\hline Oxides & $\mathrm{Al}_{2} \mathrm{O}_{3}$ & $\mathrm{CoO}$ & $\mathrm{NiO}$ & $\mathrm{Ta}_{2} \mathrm{O}_{5}$ \\
\hline$\Delta \mathrm{G}^{\circ}$ & -885 & -318 & -281 & -629 \\
\hline
\end{tabular}



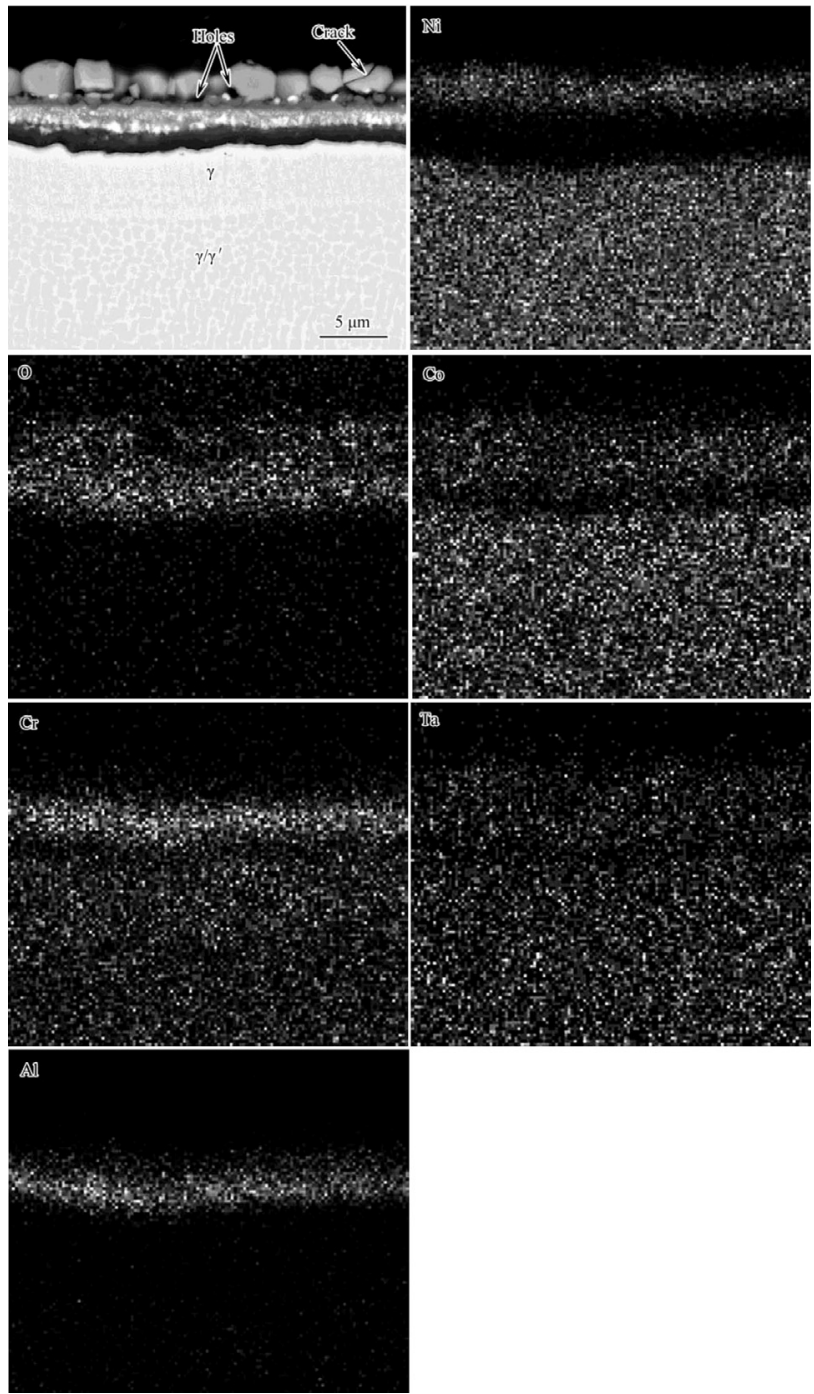

Figure 7: Cross-section morphology and EDS mapping of DD6 superalloy oxidized at $1100{ }^{\circ} \mathrm{C}$ for $100 \mathrm{~h}$

Figure 8 presents cross-section morphologies and EDS results of NiCrAlY coating oxidized at $1100{ }^{\circ} \mathrm{C}$ for 100 h. As shown in Figure 8a, a continuous oxide scales covered on the NiCrAlY coating. Figure 8b shows the magnified oxide scales morphology to further observe the detail, it can be clearly seen that the layered oxide scales include a thin $\theta-\mathrm{Al}_{2} \mathrm{O}_{3}$ outer layer, and a thick, dense and adherent $\alpha-\mathrm{Al}_{2} \mathrm{O}_{3}$ inner layer. Z. Y. Liu, et al. ${ }^{17}$ have found that the coatings with a higher $\mathrm{Al}$ content had a stronger tendency to generate $\theta-\mathrm{Al}_{2} \mathrm{O}_{3}$ than those with a lower one. A $\theta-\mathrm{Al}_{2} \mathrm{O}_{3}$ scale grows much faster than a $\alpha-\mathrm{Al}_{2} \mathrm{O}_{3}$ one does. Actually, the superfine columnar crystals and nanocrystallites in the NiCrAlY coating provided many short-circuit channels for the fast diffusion of $\mathrm{Al}$ in the initial oxidation stage, which promoted the formation of the fast-growing $\theta-\mathrm{Al}_{2} \mathrm{O}_{3}{ }^{18-19}$ The $\theta-\mathrm{Al}_{2} \mathrm{O}_{3}$ might transform to $\alpha-\mathrm{Al}_{2} \mathrm{O}_{3}$ after further oxidation, and generally this transformation is observed to occur close to or at the oxide/metal interface, but not at the gas/oxide interface, ${ }^{20}$ thus the blade-like $\theta-\mathrm{Al}_{2} \mathrm{O}_{3}$ morphology at the gas/oxide interface was preserved while the thickness of the $\alpha-\mathrm{Al}_{2} \mathrm{O}_{3}$ layer became thicker due to the transformation. The NiCrAlY coating exhibited excellent oxidation resistance because of the thick, dense and adherent $\alpha-\mathrm{Al}_{2} \mathrm{O}_{3}$ layer preventing the diffusion of $\mathrm{O}$ and $\mathrm{Al}$.

It can clearly be seen from Figure 8a that there is an outer degraded layer below the oxide scales as the Al consumption during oxidation had led to the transformation of $\beta$ to $\gamma^{\prime}$ to $\gamma$, beneath that there are an unaffected coating, an interdiffusion zone (IDZ) and an secondary reaction zone (SRZ) in sequence. As shown in Figure 8c, the inward diffusion of $\mathrm{Al}, \mathrm{Cr}$ in the coating and the outward diffusion of Ta, W, Co in the superalloy substrate occurred due to the chemical potential difference. Like the other MCrAlY/superalloy system, ${ }^{21}$ the IDZ and SRZ always form below the coating due to the element interdiffusion between NiCrAlY coating and DD6 substrate. However, significantly, different from the other $\mathrm{MCrAlY} /$ superalloy system, the formation of deleterious Kirkendall voids was not observed between the coating and the substrate, which may be mainly due to the gradient transition of the elements between the coating and the substrate.
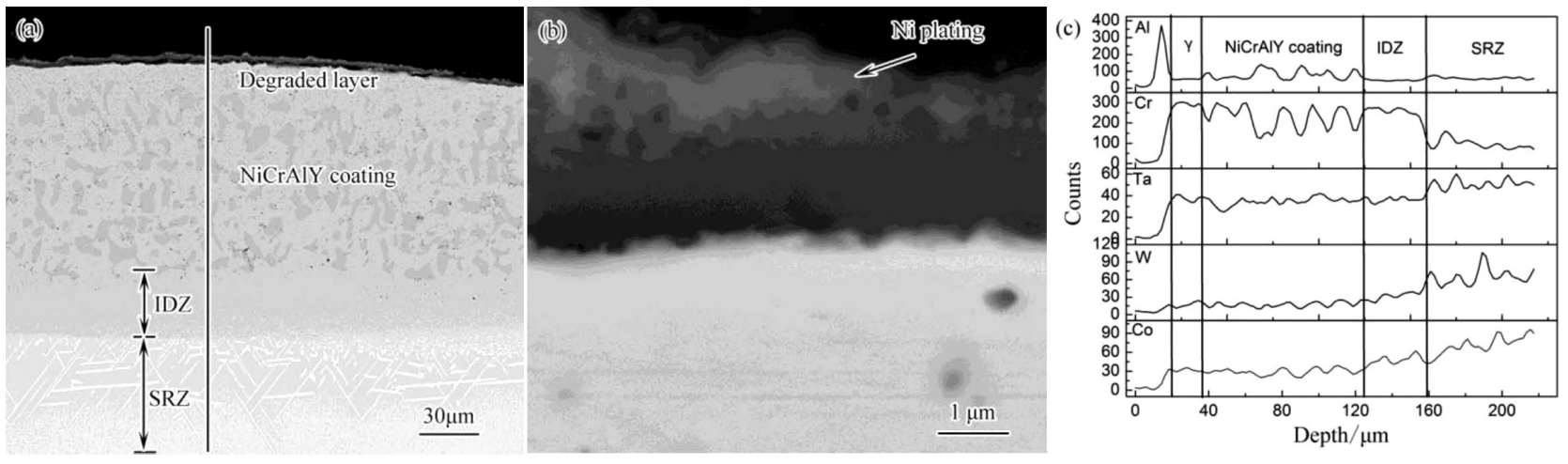

Figure 8: NiCrAlY coating oxidized at $1100{ }^{\circ} \mathrm{C}$ for $100 \mathrm{~h}$ : a) overall cross-section morphology, b) magnified oxide scales morphology, c) EDS line scanning 


\section{CONCLUSIONS}

The as-deposited NiCrAlY coating, with uniform superfine columnar crystals and nanocrystallites, is composed of $\beta$-NiAl and $\gamma$-Ni double phases.

The oxidation resistance of the DD6 superalloy was greatly improved by depositing the NiCrAlY coating at $1100{ }^{\circ} \mathrm{C}$.

The three layers of oxides, including $\mathrm{Ni}(\mathrm{Co}) \mathrm{O}$, $\mathrm{NiCr}_{2} \mathrm{O}_{4}, \mathrm{CrTaO}_{4}, \mathrm{CoTa}_{2} \mathrm{O}_{6}$ and $\alpha-\mathrm{Al}_{2} \mathrm{O}_{3}$, formed on the DD6 alloy, while two layers of oxides, $\theta-\mathrm{Al}_{2} \mathrm{O}_{3}$ and $\alpha-\mathrm{Al}_{2} \mathrm{O}_{3}$, formed on the $\mathrm{NiCrAlY}$ coating at $1100{ }^{\circ} \mathrm{C}$ for $100 \mathrm{~h}$.

The IDZ and SRZ formed below the NiCrAlY coating for the interdiffusion; however, no deleterious Kirkendall voids appeared, which may be mainly due to the gradient transition of the elements between the coating and the substrate at $1100{ }^{\circ} \mathrm{C}$ for $100 \mathrm{~h}$.

\section{Acknowledgment}

The authors are grateful for the financial support of the National Science Foundation of Liaoning Province of China (no. 201602643), and Open Fund of Liaoning Province Armament Science and Technology Key Laboratory of Shenyang Ligong University (no. 4771004kfs25).

\section{REFERENCES}

${ }^{1}$ D. K. Das, K. S. Murphy, S. Ma, T. M. Pollock, Formation of secondary reaction zones in diffusion aluminide-coated Ni-base singlecrystal superalloys containing ruthenium, Metallurgical \& Materials Transactions A, 39 (2008) 7, 1647-1657, doi:10.1007/s11661-0089534-1

${ }^{2}$ J. L. Wang, M. H. Chen, S. L. Zhu, F. H. Wang, Ta effect on oxidation of a nickel-based single-crystal superalloy and its sputtered nanocrystalline coating at $900-1100{ }^{\circ} \mathrm{C}$, Applied Surface Science, 345 (2015), 194-203, doi:10.1016/j.apsusc.2015.03.157

${ }^{3}$ J. Zhang, C. A. Guo, X. D. Lu, Q. P. Guo, High temperature oxidation behavior of arc ion plated NiCoCrAlYSi coating on gun steel, Transactions of Materials and Heat Treatment, 36 (2015) 6, 197-201, doi:10.13289/j.issn.1009-6264.2015.06.038

${ }^{4}$ J. L. Wang, M. H. Chen, L. L. Yang, S. L. Zhu, F. H. Wang, Comparative study of oxidation and interdiffusion behavior of AIP NiCrAlY and sputtered nanocrystalline coatings on a nickel-based single-crystal superalloy, Corrosion Science, 98 (2015), 530-540, doi:10.1016/j.corsci.2015.05.062

${ }^{5}$ A. E. Kudryashov, A. Y. Potanin, D. N. Lebedev, I. V. Sukhorukova, D. V. Shtansky, E. A. Levashov, Structure and properties of Cr-AlSi-B coatings produced by pulsed electrospark deposition on a nickel alloy, Surface and Coatings Technology, 285 (2015), 278-288, doi:10.1016/ j.surfcoat.2015.11.052

${ }^{6}$ N. I. Jamnapara, S. Frangini, J. Alphonsa, N. L. Chauhan, S. Mukherjee, Comparative analysis of insulating properties of plasma and thermally grown alumina films on electrospark aluminide coated $9 \mathrm{Cr}$ steels, Surface \& Coatings Technology, 266 (2015), 146-150, doi:10.1016/j.surfcoat.2015.02.028
${ }^{7}$ K. Korkmaz, Investigation and characterization of electrospark deposited chromium carbide-based coating on the steel, Surface and Coatings Technology, 272 (2015), 1-7, doi:10.1016/j.surfcoat.2015. 04.033

${ }^{8}$ T. K. Cao, S. Lei, M, Zhang, The friction and wear behavior of $\mathrm{Cu} / \mathrm{Cu}-\mathrm{MoS}_{2}$ self-lubricating coating prepared by electrospark deposition, Surface and Coatings Technology, 270 (2015), 24-32, doi:10.1016/j.surfcoat.2015.03.023

${ }^{9}$ A. A. Burkov, S. A. Pyachin. Formation of WC-Co coating by a novel technique of electrospark granules deposition, Materials \& Design, 80 (2015), 109-115, doi:10.1016/j.matdes.2015.05.008

${ }^{10}$ X. Hong, Y. F. Tan, X. L. Wang, H. Tan, T. Xu, Effects of nitrogen flux on microstructure and tribological properties of in-situ TiN coatings deposited on TC11 titanium alloy by electrospark deposition, Transactions of Nonferrous Metals Society of China, 25 (2015), 3329-3338, doi:10.1016/S1003-6326(15)63990-5

${ }^{11}$ X. Hong, Y. Tan, C. Zhou, X. Ting, Z. W. Zhang, Microstructure and tribological properties of Zr-based amorphous-nanocrystalline coatings deposited on the surface of titanium alloys by electrospark deposition, Applied Surface Science, 356 (2015), 1244-1251, doi:10.1016/j.apsusc.2015.08.233

${ }^{12}$ X. R. Wang, Z. Q. Wang, P. He, T. S. Lin, Y. Shi, Microstructure and wear properties of CuNiSiTiZr high-entropy alloy coatings on TC11 titanium alloy produced by electrospark computer numerical control deposition process, Surface and Coatings Technology, 283 (2015), 156-161, doi:10.1016/j.surfcoat.2015.10.013

${ }^{13}$ J. B. Yang, Q. P. Guo, B. Y. Zhao, H. Jin, C. A. Guo, J. Zhang, Friction and wear performance of W-Ni-Fe-Co coating electrospark deposited on CrNi3MoVA steel, Materials Review, 31 (2017) 6, 35-38, doi:10.11896/j.issn.1005-023X.2017.012.008

${ }^{14}$ Y. J. Xie, M. C. Wang, Isothermal oxidation behavior of electrospark deposited MCrAlX-type coatings on a Ni-based superalloy, Journal of Alloys \& Compounds, 480 (2009) 2, 454-461, doi:10.1016/ j.jallcom.2009.01.100

${ }^{15}$ M. Huang, Z. Y. Cheng, J. C. Xiong, J. R. Li, J. Q. Hu, Z. L. Liu, J. Zhu. Coupling between Re segregation and $\gamma / \gamma^{\prime}$ interfacial dislocations during high-temperature, low-stress creep of a nickel-based single-crystal superalloy, Acta Materialia, 76 (2014) 37, 294-305, doi:10.1016/j.actamat.2014.05.033

${ }^{16}$ Y. J. Liang and Y. C. Che, Handbook of inorganic compound of thermodynamic data, $1^{\text {nd }}$ ed., Northeastern University, Shenyang 1993, 450

${ }^{17}$ Z. Y. Liu, W. Gao, H. Gong. Anisothermal oxidation of micro-crystalline Ni-20Cr-5 Al alloy coating at $850-1280{ }^{\circ} \mathrm{C}$, Scripta Materialia, 38 (1998) 7, 1057-1063, doi:10.1016/S1359-6462(98)00008-6

${ }^{18}$ J. Doychak, J. L. Smialek, T. E. Mitchell, Transient oxidation of single-crystal $\beta$-NiAl, Metallurgical Transactions A, 20 (1989) 3, 499-518, doi:10.1007/BF02653930

${ }^{19}$ E. Schumann, The effect of Y-ion implantation on the oxidation of $\beta$-NiAl, Oxidation of Metals, 43 (1995) 1-2, 157-172, doi:10.1007/ BF01046752

${ }^{20}$ S. L. Yang, F. H. Wang, W. T. Wu, Effect of microcrystallization on the cyclic oxidation behavior of $\beta$-NiAl intermetallics at $1000^{\circ} \mathrm{C}$ in air, Intermetallics, 9 (2000) 8, 741-744, doi:10.1016/S0966-9795 (01)00059-0

${ }^{21}$ C. A. Guo , W. Wang, Y. X. Cheng, S. L. Zhu, F. H. Wang, Yttria partially stabilised zirconia as diffusion barrier between NiCrAlY and Ni-base single crystal René N5 superalloy, Corrosion Science, 94 (2015), 122-128, doi:10.1016/j.corsci.2015.01.048 